\title{
PENGARUH KONSENTRASI MEDIA PENYALUT DAN LAMA ULTRASONIKASI TERHADAP UKURAN PARTIKEL DAN AKTIVITAS ANTIOKSIDAN NANO EKSTRAK BAWANG PUTIH TUNGGAL (Allium sativum L.)
}

\section{The Effect of Concentration Coating Medium and Long Ultrasonication on Particle Size and Antioxidant Activity of Solo Garlic Nano Extract}

\author{
Christian Tri Wahyudi", Sudarma Dita Wijayanti, Harijono \\ Jurusan Teknologi Hasil Pertanian, FTP Universitas Brawijaya, Malang \\ Jl. Veteran Malang 65145 \\ *Penulis Korespondensi, Email: christian.triwahyudi@gmail.com
}

\begin{abstract}
ABSTRAK
Bawang putih mempunyai senyawa bioaktif utama, yaitu allicin, terutama karena kemampuannya sebagai antioksidan. Senyawa yang masih berukuran besar lebih sulit diserap oleh tubuh dibandingkan dengan senyawa yang berukuran nano. Salah satu metode nanoteknologi yang dapat digunakan untuk pengecilan ukuran adalah ultrasonikasi. Dalam proses tersebut sering kali digunakan zat penyalut yang ditujukan untuk memerangkap atau melapisi senyawa yang sudah diubah menjadi berukuran nano karena ultrasonikasi. Zat penyalut ini dapat melapisi senyawa bioaktif yang terdiri dari lebih dari satu komponen. Zat penyalut yang banyak digunakan adalah campuran kitosan dan Sodium Tri Polipospat (STPP). Penyalut dengan kitosan/STPP dengan konsentrasi $1.33 / 0.17 \%$ dan ultrasonikasi pada frekuensi $40 \mathrm{KHz}$ selama 30 menit merupakan perlakuan terbaik dan menghasilkan ekstrak nano dengan ukuran partikel rata - rata sebesar $240.7 \mathrm{~nm}$, viskositas sebesar 31.67 $\mathrm{cP}$, dan nilai $\mathrm{IC}_{50}$ sebesar $8024.58 \mathrm{ppm}$.
\end{abstract}

Kata Kunci : Bawang putih tunggal, Nanoteknologi, Ultrasonik

\section{ABSTRACT}

Garlic has a major bioactive compound, allicin, primarily because of it's ability as an antioxidant. Large compounds tend to be difficult to absorb by the body compared to nanosized compounds. One of nanotechnology methods that can be used for size reduction is ultrasonication. Coating agent is often used to trap or coat the compound that has been converted into nano-sized by ultrasonication. Coating agent may coat bioactive compounds comprising more than one component. The coating agent is widely used a mixture of chitosan and sodium tripolyphosphate (STPP). Coating with chitosan/STPP with concentration $1.33 / 0.17 \%$ and ultrasonication at frequency $40 \mathrm{KHz}$ for 30 minutes is the best treatment and yield nano extract with average particle size of $240.7 \mathrm{~nm}$, viscosity of $31.67 \mathrm{cP}$, and $\mathrm{IC}^{50}$ value of $8024.58 \mathrm{ppm}$.

Keywords: Solo garlic, Nanotechnology, Ultrasonication

\section{PENDAHULUAN}

Umbi bawang putih terutama umbi bawang putih tunggal diketahui mengandung zat berkhasiat dan sudah lama digunakan di dalam sistem pengobatan tradisional. Wibowo (2007) menyatakan bahwa pada bawang putih tunggal hanya ditemukan satu siung umbi pada satu rumpun tanaman.

Zat tertentu yang memiliki khasiat tersebut akan terpisah dari bahan dengan cara diekstrak sehingga dengan demikian akan mudah untuk diserap oleh tubuh (Darwis, 2000). Menurut Sidqi (2011) dalam penelitiannya menunjukkan bahwa ekstrak yang masih berukuran mikro 
memiliki bioavailabilitas rendah. Salah satu upaya yang telah dikembangkan adalah penyalutan dengan partikel nano. Ultrasonikasi merupakan salah satu metode yang dapat digunakan untuk pembuatan nano partikel.

Kitosan merupakan bahan yang sering digunakan dalam pembuatan nano partikel. Kitosan yang direaksikan dengan natrium tripolipospat (STPP) akan menghasilkan penyalut yang dapat digunakan sebagai media untuk mengecilkan ukuran. Desai dan Park (2005) membuktikan bahwa mikrosfer kitosan yang berikatan silang dengan tripolifosfat dapat digunakan sebagai penyalut obat dengan metode pengeringan semprot (Spray Drying). Oleh sebab itu, penelitian ini bertujuan untuk mendapatkan kombinasi antara konsentrasi media penyalut kitosan dan lama waktu ultrasonikasi yang dapat menghasilkan partikel bawang putih tunggal berukuran nano dengan kemampuan antioksidan tinggi.

\section{BAHAN DAN METODE}

\section{Bahan}

Bahan utama yang digunakan dalam penelitian ini adalah tanaman bawang putih tunggal (Allium sativum L.) yang diperoleh dari pasar di kota Malang. Bahan yang digunakan ekstraksi adalah Etanol $96 \%$ dan kertas saring. Sedangkan bahan yang digunakan untuk analisis adalah etanol 96\%, aquades, asam asetat, kitosan, STPP, kertas saring, dan DPPH 0,2 mM.

\section{Alat}

Alat yang digunakan adalah blender (merk oxone 290 watt), timbangan analitik (merk ohaus kapasitas 210 gram), vacuum rotary evaporator (merk IKA power input 1400 watt), ultrasound chamber (merk elma), spektrofotometer (merk cole parmer rentang panjang gelombang $100-1200 \mathrm{~nm}$ ), Particle Size Analysis (PSA)(merk malvern dengan rentang pembacaan $0,4-10.000 \mathrm{~nm}$ ), dan spektrometer infra merah untuk uji Fourier Transform Infra Red (FTIR) (merk Type : FT 1000).

\section{Metode Penelitian}

Metode yang digunakan pada penelitian ini adalah percobaan dengan menggunakan Rancangan Acak Kelompok (RAK), yang terdiri dari 2 faktor perlakuan dengan 3 ulangan. Faktor pertama adalah konentrasi media penyalut. Faktor kedua adalah lama waktu ultrasonikasi.

Kombinasi perlakuan :

Faktor 1 merupakan Konsentrasi media penyalut yang digunakan $(\mathrm{P})$, yaitu :

$$
\begin{aligned}
& \mathrm{P}_{1}=\text { Kitosan/STPP : } 0 / 0 \% \\
& \mathrm{P}_{2}=\text { Kitosan/STPP }: 1.33 / 0.17 \% \\
& \mathrm{P}_{3}=\text { Kitosan/STPP }: 2.67 / 0.17 \%
\end{aligned}
$$

Faktor 2 merupakan Lama waktu ultrasonikasi (T), yaitu :

$$
\begin{aligned}
& \mathrm{T}_{1}=30 \text { menit } \\
& \mathrm{T}_{2}=60 \text { menit }
\end{aligned}
$$

\section{Tahapan Penelitian}

Diagram alir pembuatan ekstrak bawang putih tunggal (Allium sativum L.) adalah sebagai berikut (modifikasi Priskila, 2008) :

a. Tanaman bawang putih tunggal disortasi dan dibersihkan dengan air mengalir. Kemudian bawang dikupas dan kulit bawang dibuang.

b. Kemudian bawang dihaluskan dengan menggunakan blender hingga terbentuk bubur .

c. Hasil pemblenderan kemudian ditimbang sebesar 60 gram. 
d. Dilakukan proses ekstraksi dengan metode maserasi dengan menggunakan pelarut etanol, perbandingan antara bawang putih tunggal dengan pelarut 1:4 (b/v) dilakukan selama 24 jam dengan Shaker.

e. Hasil ekstraksi di saring menggunakan kertas saring dan ampas dibuang.

f. Diperoleh ekstrak bawang putih tunggal.

g. Dilakukan proses evaporasi pada cairan ekstrak dengan vacuum rotary evaporator pada suhu $40^{\circ} \mathrm{C}$ selama \pm 60 menit.

h. Didapatkan ekstrak kental Bawang putih tunggal sebanyak 46 gram.
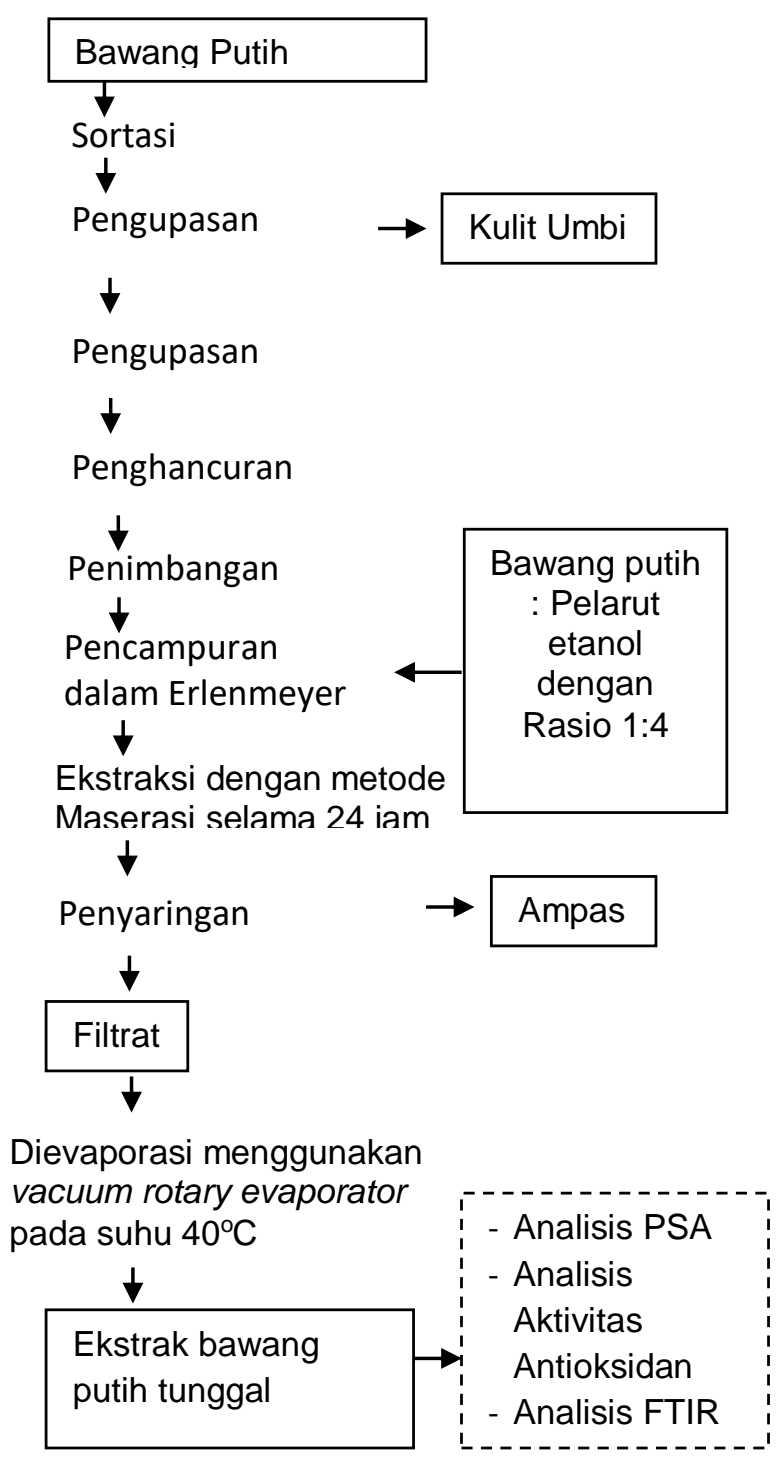

Gambar 1. Diagram Alir Pembuatan Ekstrak Bawang Putih Tunggal

Kemudian dilanjutkan dengan tahapan pembuatan nano ekstrak bawang putih tunggal.

a. Larutan kitosan yang dilarutkan menggunakan asam asetat $2 \%$ dimbil sebanyak $100 \mathrm{ml}$ dengan konsentrasi berbeda ( $0 \%, 2 \%$, dan 4\%) dimasukkan ke dalam erlenmeyer $250 \mathrm{ml}$.

b. Ditambahkan $50 \mathrm{ml}$ larutan STPP $0.5 \%$.

c. Diperoleh larutan kitosan - STPP dengan kadar kitosan 0\%, 1.33\%, dan $2.67 \%$ dan masing - masing berkadar STPP 0,17\%.

d. Masing - masing larutan diaduk dengan menggunakan magnetic stirrer selama 10 menit.

e. Ditambahkan ekstrak kental bawang putih tunggal sebanyak $5 \mathrm{mg}$ dari total 46 gram ekstrak kental. 
f. Campuran diaduk kembali dengan menggunakan magnetic stirrer selama 5 menit sampai tercampur merata menjadi satu.

g. Dilakukan penyaringan menggunakan alat saring berpori mikro ( 0.45 mikro) dan diperoleh filtrat sebanyak kurang lebih $137 \mathrm{~mL}$.

h. Kemudian filtrat dibagi menjadi dua bagian dan masing - masing diultrasonikasi pada 30 menit dan 60 menit.

i. Didapatkan ekstrak bawang putih tunggal berukuran nano.

j. Masing - masing kombinasi perlakuan diulang tiga kali.

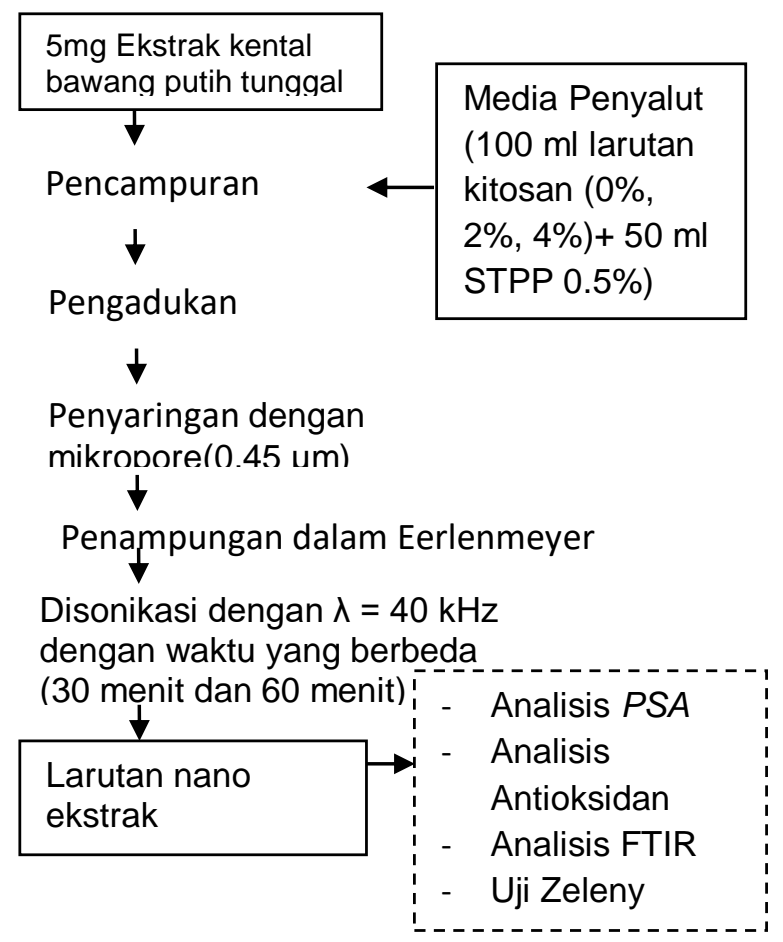

Gambar 2. Diagram Alir Pengecilan Ukuran Partikel Ekstrak Bawang Putih Tunggal

\section{Prosedur Analisis}

Pengamatan dilakukan pada produk nano ekstrak bawang putih tunggal yang meliputi :

a. Analisis Particle Size Analysis ( Sulistiyono, 2012 )

Analisis Particle Size Analysis (PSA) bertujuan untuk mengukur ukuran partikel suatu bahan menggunakan metode sesuai manual. Analisis ini sangat bermanfaat bagi penelitian nano teknologi.

b. Analisis Aktivitas Antioksidan metode DPPH( Kekuda, 2009)

Analisis aktivitas antioksidan khususnya $\mathrm{IC}_{50}$ dengan metode DPPH ini bertujuan untuk mengetahui kandungan antioksidan dalam bahan pangan untuk mampu menghambat $50 \%$ radikal bebas. DPPH merupakan senyawa radikal bebas yang bersifat tidak stabil. Pada pengujian ini sampel ekstrak umbi bawang lanang diambil dari ekstrak kental hasil evaporasi. Sedangkan untuk sampel perlakuan diambil dari larutan campuran ekstrak sebanyak $5 \mathrm{mg}$ dengan larutan kitosan-STPP.

c. Analisis Fourier Transform Infra Red (Luyt et al., 2009)

Analisis FTIR ini bertujuan untuk mengetahui ikatan senyawa yang ada dalam bahan pangan dengan menggunakan gelombang infra merah. Ikatan tersebut akan membentuk peak yang akan terbaca pada nilai tertentu. 
d. Analisis Viskositas (Budianto, 2008)

Analisis viskositas bertujuan untuk mengetahui kekentalan suatu bahan atau larutan. Semakin tinggi nilai viskositas suatu bahan semakin kental bahan tersebut.

\section{HASIL DAN PEMBAHASAN}

\section{Rendemen dan Karakteristik Ekstrak Etanol Umbi Bawang Putih Tunggal}

Dari hasil analisis ekstrak bawang putih tunggal sebelum dilakukan perlakuan didapatkan hasil yang dapat dilihat pada Tabel 1 .

Tabel 1. Rendemen dan Karakteristik Ekstrak Etanol Umbi Bawang Putih Tunggal

\begin{tabular}{lc}
\hline \multicolumn{1}{c}{ Paramenter } & Nilai \\
\hline Rendemen (\%) & 29.68 \\
Aktivitas Antioksidan IC $50(\mathrm{ppm})$ & 875.65 \\
Particle Size Analysis (nm) & 4108 \\
Viskositas (cP) & 46 \\
\hline
\end{tabular}

Rendemen ekstrak bawang putih tunggal yaitu sebesar $29.68 \%$. Rendemen ekstrak yang tinggi menunjukkan bahwa jumlah senyawa yang tersari dari bahan baku tinggi. Sebaran ukuran partikel ekstrak bawang putih tunggal dari hasil PSA adalah 450 - $4200 \mathrm{~nm}$ dengan rata - rata sebesar $4.108 \mathrm{~nm}$. Pada ekstrak bawang putih tunggal nilai rerata ukuran partikel sebesar $4.108 \mathrm{~nm}$ belum dapat dikatakan sebagai nano ekstrak. Perlakuan ultrasonikasi dengan penyalutan kitosan diharapkan dapat menghasilkan ekstrak bawang putih tunggal dengan ukuran nano.

Hasil analisis aktivitas antioksidan $\mathrm{IC}_{50}$ dengan metode DPPH pada ekstrak bawang putih tunggal adalah $875.65 \mathrm{ppm}$. Nilai $\mathrm{IC}_{50}$ sebesar $875.65 \mathrm{ppm}$ ini memiliki arti sebanyak $1.75 \mathrm{mg}$ ekstrak bawang putih tunggal mampu menghambat $50 \%$ radikal bebas dari $0.078 \mathrm{mg}$ DPPH. Sedangkan nilai viskositas ekstrak bawang putih tunggal yang diperoleh adalah sebesar 46 cP. Semakin tinggi nilai viskositasnya maka semakin kental zat cair tersebut.

Tabel 2. Gugus Kimia pada Ekstrak Etanol dari Umbi Bawang Putih Tunggal

\begin{tabular}{|c|c|c|c|}
\hline No. & $\begin{array}{c}\text { Bilangan Gelombang } \\
(1 / \mathrm{cm})\end{array}$ & Intensitas (\%) & Jenis Gugus Fungsi \\
\hline \multirow[b]{2}{*}{1} & 522.6 & 59.92 & \multirow[b]{2}{*}{ Gugus C - S (disulfida ulur) } \\
\hline & 649.4 & 60.00 & \\
\hline 2 & 932.1 & 75.51 & Alkena tekuk $\mathrm{C}=\mathrm{C}$ \\
\hline \multirow[b]{2}{*}{3} & 1026.6 & 60.00 & \multirow[b]{2}{*}{ Gugus C - C } \\
\hline & 1054.8 & 60.50 & \\
\hline 4 & 1130.2 & 68.84 & Gugus $\mathrm{S}-\mathrm{H}$ sulfonamida \\
\hline 5 & 1378.9 & 62.30 & - $\mathrm{CH}_{3}$ tekuk \\
\hline 6 & 1637.0 & 52.23 & Gugus $C=C$ \\
\hline 7 & 2119.2 & 80.00 & Gugus S - H \\
\hline 8 & 2942.6 & 61.25 & Gugus $\mathrm{C}-\mathrm{H}$ alkana ulur \\
\hline 9 & 3424.9 & 18.75 & Adanya ikatan hidrogen \\
\hline
\end{tabular}

Hasil analisis FTIR (Fourier Transform Infra Red) ekstrak umbi bawang putih tunggal disajikan pada Gambar 3. Etanolat umbi bawang putih tunggal mempunyai gugus C-S (bilangan gelombang 522.6 dan 649.4), gugus $\mathrm{C}=\mathrm{C}$ (Bilangan gelombang 932.1 dan 1637.0), 
gugus C-C (bilangan gelombang 1026.6 dan 1054.8), gugus S-H sulfonamida (bilangan gelombang 1130.2), gugus $-\mathrm{CH}_{3}$ tekuk (bilangan gelombag 1378.9), gugus $\mathrm{S}-\mathrm{H}$ (bilangan gelombang 2119.2), gugus $\mathrm{C}-\mathrm{H}$ (bilangan gelombang 2942.6), dan ikatan hidrogen (bilangan gelombang 3424.9). Hal ini membuktikan bahwa dalam ekstrak bawang putih tunggal yang dianalisis terdapat gugus fungsi senyawa sulfida yaitu diallyl sulfida dan allyl sulfida, dimana dua komponen tersebut merupakan turunan dari allicin yang menimbulkan bau yang khas. Hal ini sesuai dengan pendapat Yuniastuti (2006) bahwa bawang putih yang diekstrak dengan menggunakan metode ekstraksi maserasi dengan pelarut etanol akan menghasilkan dua senyawa utama yaitu diallyl sulfida dan allyl sulfida.

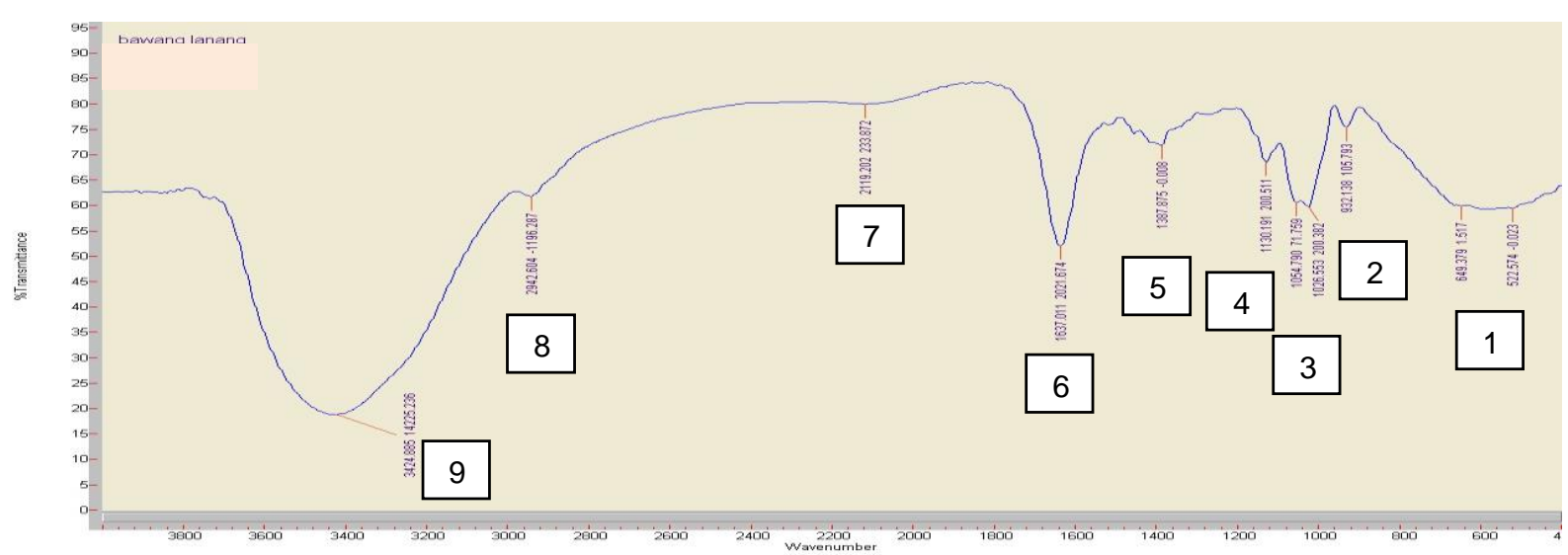

Gambar 3. Hasil Analisis FTIR Ekstrak Bawang Putih Tunggal

Ket : Nomor pada gambar merupakan nomor dari bilangan gelombang sesuai yang tertera pada tabel 2

\section{Kitosan Sebagai Media Penyalut}

Pada penelitian ini menggunakan kitosan sebagai bahan penyalut yang direaksikan dengan STPP. Kitosan - STPP akan bereaksi secara kimia yang strukturnya akan membentuk seperti jaring dan akan melapisi ekstrak. Diduga kitosanlah yang mempengaruhi pengecilan ukuran dari sebuah partikel. Kitosan sendiri diduga memiliki aktivitas antioksidan yang cukup tinggi, sehingga disini kitosan diuji sebelum direaksikan dengan ekstrak bawang putih tunggal.

Nilai aktivitas antioksidan terutama $\mathrm{IC}_{50}$ dalam penelitian ini didapatkan hasil sebesar 10204.08 ppm. Nilai $I_{50}$ tersebut memiliki arti sebanyak 20.42 mg ekstrak kitosan mampu menghambat $50 \%$ radikal bebas dari $0.078 \mathrm{mg}$ DPPH. Sebaran ukuran partikel larutan kitosan dari hasil PSA adalah $50-1150 \mathrm{~nm}$ dengan rata - rata sebesar $473.4 \mathrm{~nm}$. Hal ini memberikan harapan bahwa kitosan sebagai penyalut dapat memerangkap etanolat bawang putih tunggal menjadi partikel berukuran nano.

\section{Sifat- Sifat Nano Ekstrak Etanol Umbi Bawang Putih tunggal}

Tabel 2. Data Karakteristik Kimia Nano Ekstrak Bawang Putih Tunggal

\begin{tabular}{|c|c|c|c|c|c|c|}
\hline Parameter & $\begin{array}{l}\text { Kitosan/ } \\
\text { STPP } \\
\text { 0/0\%, } \\
\text { Ultrasonik } \\
30 \text { menit }\end{array}$ & $\begin{array}{c}\text { Kitosan/ } \\
\text { STPP } \\
1.33 / 0.17 \% \\
\text {, Ultrasonik } \\
30 \text { menit }\end{array}$ & $\begin{array}{c}\text { Kitosan/ } \\
\text { STPP } \\
2.67 / 0.17 \\
\% \text {, } \\
\text { Ultrasonik } \\
30 \text { menit } \\
\end{array}$ & $\begin{array}{l}\text { Kitosan/ } \\
\text { STPP } \\
\text { 0/0\%, } \\
\text { Ultrasonik } \\
60 \text { menit }\end{array}$ & $\begin{array}{c}\text { Kitosan/ } \\
\text { STPP } \\
1.33 / 0.17 \\
\% \text {, } \\
\text { Ultrasonik } \\
60 \text { menit } \\
\end{array}$ & $\begin{array}{c}\text { Kitosan/ } \\
\text { STPP } \\
2.67 / 0.17 \\
\%, \\
\text { Ultrasonik } \\
60 \text { menit }\end{array}$ \\
\hline Viskositas(cP) & 23.3 & 31.67 & 143.67 & 1.33 & 33 & 63.33 \\
\hline $\begin{array}{l}\text { Aktivitas Antioksidan } \\
\left(\mathrm{IC}_{50}\right)(\mathrm{ppm})\end{array}$ & $17 \varepsilon$ & 8 & 30274.72 & 2 & 7417.09 & 5047.40 \\
\hline PSA (nm) & 1098.4 & 240.7 & 252.9 & 1897.2 & 355.9 & 394.1 \\
\hline
\end{tabular}




\section{a. Viskositas}

Larutan kitosan yang bereaksi dengan STPP pun akan membentuk gel yang disebut dengan sistem hidrokoloid dimana hidrokoloid sangat berpengaruh pada kekentalan suatu larutan. Hasil penelitian menunjukkan bahwa nilai viskositas dari nano ekstrak bawang putih tunggal dengan kombinasi konsentrasi kitosan dan lama waktu ultrasonikasi berkisar antara $2-142 \mathrm{cP}$.

Data tersebut menunjukkan bahwa viskositas nano ekstrak bawang putih tunggal mengalami peningkatan dengan kenaikan konsentrasi kitosan dari $0 \%$ sampai dengan $2.67 \%$, sedangkan lama ultrasonikasi sampai 60 menit memberikan pengaruh yang bervariasi, tergantung pada konsentrasi kitosan. Viskositas tertinggi diperoleh pada kombinasi perlakuan konsentrasi kitosan/STPP 2.67/0.17\% dan lama waktu ultrasonikasi 30 menit (143.67 cP) dan nilai terendah pada kombinasi perlakuan konsentrasi kitosan/STPP $0 / 0 \%$ dan lama ultrasonikasi 60 menit (11.33 cP).

Menurut Budianto (2008) bahwa viskositas suatu larutan dipengaruhi konsentrasinya, semakin tinggi konsentrasinya maka semakin tinggi pula nilai viskositasnya. Lama waktu ultrasonikasi berpengaruh sebaliknya terhadap viskositas (Kencana,2009). Menurut Jin et al. (2008),Semakin lama waktu ultrasonikasi pada larutan kitosan akan menyebabkan terpotongnya rantai kimiawi kitosan dan membuat sistem gel pada kitosan menjadi rusak. Data viskositas pada penggunaan kitosan/STPP 0/0\% lebih rendah pada sonikasi 60 menit dibandingkan sonikasi 30 menit. Sonikasi dapat menyebabkan degradasi pada molekul terbesar pada larutan kitosan.

\section{b. Aktivitas Antioksidan : $\mathbf{I C}_{50}$}

Hasil pengujian nilai $\mathrm{IC}_{50}$ nano ekstrak bawang putih tunggal dengan kombinasi konsentrasi kitosan dan lama waktu ultrasonikasi mempunyai rentang yang cukup besar, antara 5000 31000 ppm.

Data ini menunjukkan bahwa nilai $I_{50}$ nano ekstrak bawang putih tunggal pada lama waktu sonikasi 30 menit terjadi penurunan dan kembali meningkat pada konsentrasi kitosan/STPP $2.67 / 0.17 \%$. Sedangkan pada lama waktu sonikasi 60 menit terjadi penurunan nilai $I_{50}$. Penggunaan kitosan dengan Konsentrasi lebih tinggi nampaknya dapat mengurangi efek penurunan kemampuan antioksidan. Sidqi (2011) dalam penelitiannya tentang nano ekstrak temulawak yang disalut menggunakan kitosan diperoleh fakta bahwa kitosan sebagai penyalut memberikan efek antioksidan yang cukup tinggi.

Hasil perhitungan nilai $\mathrm{IC}_{50}$ pada perlakuan tersebut menunjukkan adanya pengaruh ultrasonik terhadap kestabilan nilai $\mathrm{IC}_{50}$. Nilai $\mathrm{IC}_{50}$ terbaik berada pada perlakuan konsentrasi kitosan/STPP 2.67/0.17\% dengan lama waktu sonikasi 60 menit. Dari hasil tersebut dapat dilihat peran kitosan sebagai penyalut dapat melindungi senyawa yang tersalut kitosan dari kerusakan yang ditimbulkan oleh efek ultrasonikasi. Namun nilai $\mathrm{IC}_{50}$ pada semua perlakuan masih menunjukkan hasil yang rendah hal ini dikarenakan ekstrak yang digunakan dalam perlakuan ini masih terbilang sedikit yaitu sebesar $5 \mathrm{mg}$ dalam $150 \mathrm{ml}$ larutan kitosan-STPP.

\section{c. Ukuran Partikel dengan Particle Size Analysis (PSA)}

Dari hasil pengujian nano ekstrak bawang putih tunggal kombinasi konsentrasi kitosan dan lama waktu ultrasonikasi mempunyai rentang nilai antara $240-2000 \mathrm{~nm}$.

Data diatas menunjukkan bahwa nilai ukuran partikel nano ekstrak bawang putih tunggal mengalami penurunan pada konsentrasi kitosan/STPP 1.33/0.17\% dan kembali naik pada konsentrasi kitosan/STPP $2.67 / 0.17 \%$, sedangkan mengalami peningkatan pada lama ultrasonikasi 60 menit dibandingkan dengan lama ultrasonikasi 30 menit. Ukuran partikel terkecil berada pada kombinasi perlakuan kitosan/STPP 1.33/0.17\% dan lama ultrasonik 30 menit yaitu sebesar $240.7 \mathrm{~nm}$, sedangkan nilai ukuran partikel yang terbesar terdapat pada perlakuan kitosan/STPP 0\% dan lama ultrasonik 60 menit yaitu sebesar $1897.20 \mathrm{~nm}$.

Dapat dilihat bahwa kitosan/STPP sebagai media penyalut memberikan pengaruh terhadap pengecilan ukuran partikel yang terbentuk. Menurut Sidqi (2011) dalam penelitiannya tentang nano ekstrak temulawak dengan metode ultrasonikasi menggunakan penyalut kitosan mengatakan bahwa kitosan yang direaksikan dengan STPP dengan 
konsentrasi tertentu dapat dipakai sebagai penyalut yang membantu senyawa organik dalam mengecilkan ukuran partikel.

\section{d. Gugus fungsi dengan Fourier transform Infra Red (FTIR)}

Fourier Transform Infra Red (FTIR) merupakan metode uji yang digunakan untuk mengetahui ikatan molekul yang terdapat dalam suatu bahan atau sampel (Yuniastuti, 2006). Berikut ini gambar mengenai perbandingan antara ekstrak bawang putih tunggal dengan ekstrak bawang putih tunggal yang diberikan kitosan dengan konsentrasi yang berbeda. Gambar perbandingan uji FTIR disajikan pada Gambar 4.

Dari hasil FTIR diatas dapat dilihat bahwa setelah dilakukan perlakuan apabila dibandingkan dengan ekstrak bawang putih tunggal ada beberapa peak yang hilang pada perlakuan dan ada peak yang terbaca pada grafik FTIR. Pada spektra kurva A terdapat 3 peak yang merupakan gugus utama penyusun senyawa organosulfur diallyl sulfida dan allyl sulfida. Bilangan gelombang peak penyusun senyawa organosulfur terebut berturut - turut adalah 522.6, 1130.2, dan 2119.2. Spektra kurva B memiliki 3 pita serapan utama yaitu pada bilangan gelombang 3459.2, 1639.6, dan 1021.2. Menurut Kusumaningsih (2004), kitosan terbentuk dari 3 pita serapan yang terbaca pada pengujian FTIR. Pita serapan yang leber dan kuat pada bilangan gelombang $3450-3200$. Pita serapan kedua berada pada bilangan gelombang 1220 - 1020 menunjukkan gugus amino bebas primer $\left(-\mathrm{NH}_{2}\right)$. Pita serapan terakhir berada pada bilangan gelombang 1640 -1560 menunjukkan vibrasi bending $\mathrm{N}-\mathrm{H}$.

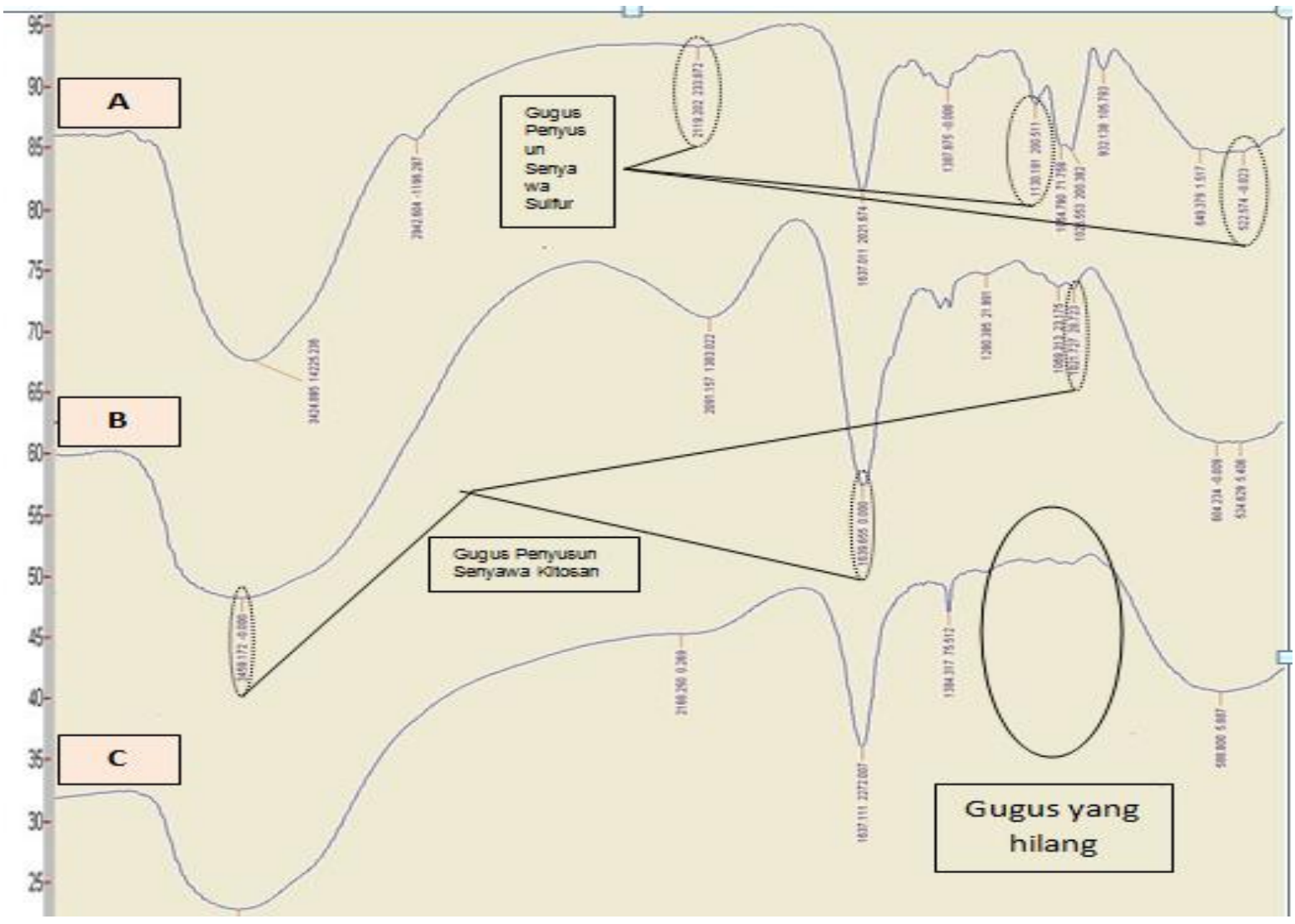

Gambar 4 grafik perbandingan Uji FTIR Nano Ekstrak Bawang Putih Tunggal Keterangan = A : Kurva Uji FTIR Ekstrak Etanol Bawang Putih Tunggal

B : Kurva Uji FTIR Perlakuan Kitosan dan Ultrasonik C : Kurva Uji FTIR Perlakuan tanpa Kitosan dan Ultrasonik 
Perlakuan Gelombang Ultrasonik selain dapat mengecilkan ukuran, namun juga dapat memberikan efek lain yang bersifat merusak. Salah satu sifat yang diberikan gelombang ultrasonik adalah rusaknya senyawa antioksidan dan menimbulkan senyawa radikal. Kitosan selain dapat digunakan sebagai penyalut yang dapat memperkecil ukuran juga dapat digunakan untuk melindungi senyawa dari kerusakan yang ditimbulkan oleh perlakuan gelombang ultrasonik.

Dari gambar 4 dapat diketahui bahwa perlakuan ultrasonik dapat mempengaruhi kerusakan beberapa gugus fungsi yang menyusun senyawa organosulfur yang tidak dilapisi oleh kitosan. Hal tersebut dapat terlihat dari kurva $\mathrm{A}$ apabila dibandingkan dengan kurva $\mathrm{C}$, di mana hilangnya bilangan gelombang 1130.2 pada kurva $\mathrm{C}$. Tidak hanya Bilangan gelombang tersebut yang hilang. Beberapa peak pada kurva $C$ banyak yang tidak terbaca. Apabila kurva $\mathrm{B}$ dibandingkan dengan kurva $\mathrm{C}$ terlihat pula bahwa sebagian bilangan gelombang yang menyusun kitosan juga hilang. Hal ini membuktikan bahwa perlakuan ultrasonik memberikan pengaruh terhadap gugus fungsi penyusun kitosan maupun senyawa organosulfur. Hal ini juga sesuai dengan pendapat yang dilaporkan Kencana (2009) dalam penelitiannya mengenai pengaruh perlakuan sonikasi terhadap kitosan.

\section{Pemilihan Perlakuan Terbaik}

Perlakuan terbaik ditentukan ditentukan melalui metode multiple atribute (Zeleny, 1982). Parameter yang digunakan adalah viskositas, ukuran Partikel, dan $\mathrm{IC}_{50}$. Seluruh parameter diharapkan memiliki nilai ideal minimal. Nilai perlakuan terbaik didapatkan dari jumlah nilai L1, L2 dan Lmax. Nilai terendah dari jumlah nilai L merupakan perlakuan terbaik dari seluruh perlakuan. Perlakuan terbaik pada nano ekstrak bawang putih tunggal terletak pada perlakuan konsentrasi kitosan/STPP 1.33/0.17\% dan lama waktu ultrasonikasi 30 menit.

Nilai perbandingan perlakuan terbaik dengan ekstrak bawang putih tunggal dapat dilihat pada Tabel 2.

Tabel 3. Perbandingan Perlakuan terbaik dengan Ekstrak Bawang Putih Tunggal

\begin{tabular}{lcc}
\hline \multicolumn{1}{c}{ Parameter } & $\begin{array}{c}\text { Ekstrak Bawang } \\
\text { Putih Tunggal }\end{array}$ & $\begin{array}{c}\text { Nano Ekstrak Bawang } \\
\text { Putih Tunggal }\end{array}$ \\
\cline { 2 - 3 } & Hasil Analisis & Perlakuan Terbaik \\
\hline PSA $(\mathrm{nm})$ & 4108 & 240.7 \\
Viskositas $(\mathrm{cP})$ & 46 & 3167.33 \\
Aktivitas Antioksidan $\left(\mathrm{IC}_{50}\right)(\mathrm{ppm})$ & 875.65 & 8024.58 \\
\hline
\end{tabular}

Pada tabel 3 terlihat bahwa beberapa parameter terjadi peningkatan dan beberapa mengalami penurunan penurunan. Pada analisis ukuran partikel menggunakan uji PSA terlihat penurunan dari nilai $4108 \mathrm{~nm}$ menjadi $240.7 \mathrm{~nm}$. Hal ini membuktikan penelitian nano ekstrak bawang putih tunggal dengan kombinasi penyalut kitosan-STPP dapat menurunkan ukuran partikel. Sedangkan untuk nilai viskositas mengalami penurunan nilai yaitu dari $46 \mathrm{cP}$ menjadi 31.67 cP. Semakin tinggi nilai viskositas semakin kental larutan tersebut. Sedangkan nilai aktivitas antioksidan $\mathrm{IC}_{50}$ mengalami kenaikkan dari 875.65 ppm menjadi 8.024.58 ppm. Tetapi kandungan antioksidan tersebut mengalami penurunan atau bersifat sangat lemah. Hal ini dikarenakan pengaruh dari penggunaan gelombang ultrasonik yang terlalu lama dapat menurunkan nilai aktivitas antioksidan karena gelombang ultrasonik dapat menimbulkan radikal bebas (Pingret et al., 2013).

\section{SIMPULAN}

Berdasarkan penelitian yang telah dilakukan diketahui bahwa perlakuan konsentrasi kitosan dan lama waktu ultrasonikasi mempengaruhi ukuran partikel dan aktivitas antioksidan (nilai $I_{50}$ ). Kombinasi perlakuan terbaik yang diperoleh melalui metode multiple atribute adalah penggunaan penyalut dengan rasio kitosan/STPP sebesar $1.33 / 0.17 \%$ dan lama 
waktu Ultrasonikasi 30 menit. Perlakuan terbaik menunjukkan nilai Aktivitas antioksidan $\mathrm{IC}_{50}$ sebesar $802.58 \mathrm{ppm}$, nilai viskositas sebesar $31.67 \mathrm{cP}$, dan nilai analisis ukuran partikel adalah sebesar $240.7 \mathrm{~nm}$.

\section{DAFTAR PUSTAKA}

Budianto, A. 2008. Metode Penentuan Koefisien Kekentalan Zat Cair dengan Menggunakan Regresi linear Hukum Stokes. Seminar Nasional IV SDM Teknologi Nuklir. Yogyakarta.

Darwis, D. 2000. Teknik Dasar Laboratorium Dalam Penelitian Senyawa Bahan Alam Hayati. Workshop pengembangan Sumber Daya Manusia Dalam Bidang Kimia Organik Bahan Alam Hayati. FMIPA Universitas Andalas. Padang.

Desai, K. and Park, H. 2005. Preparation and Characterization of Drug - Loaded Chitosan Tripolyphosphate Microspheres by Spray Drying. Drug Development Res. 64 : $114-$ 128.

Hernawan, U. dan Setyawan, A. 2003. Senyawa Organosulfur Bawang Putih (Allium sativum L.) dan Aktivitas Biologinya. Biofarmasi 1:2, 65-76.

Jin L, Jun C, and Lihong F. 2008. Effect of Sonolysis on Kinetics and Physicochemical Properties of Treated Chitosan. Journal of Applied Polymer Science 109, 2417-2425.

Karina, Z. 2015. Ekstraksi Senyawa Antioksidan Daun Sirsak (Annona muricata L.) dengan Metode Ultrasonik (Kajian Jenis Pelarut dan Umur Daun). Skripsi UB. Malang.

Kencana, A. 2009. Perlakuan Sonikasi Terhadap Kitosan : Viskositas dan Bobot Molekul Kitosan. Skripsi IPB. Bogor.

Kim, S. M. and Zayas, J. F. 1989. Processing Parameters of Chymosin Extraction by Ultrasound. Journal of Food Science 54:3, 700-703.

Pingret D, Sylvie A, Tixier F, and Chemat F. 2013. Degradation During Application of Ultrasound in Food Processing : A Review. Journal Food Control 31:593-606.

Sidqi, T. 2011. Pembuatan dan Karakterisasi Nanopartikel Ekstrak Temulawak dengan Metode Ultrasonikasi. Tugas akhir Sarjana Science. Institut Pertanian Bogor. Bogor.

Untari. 2010. Bawang Putih Sebagai Obat Paling Mujarab bagi Kesehatan. Gaster 7:1, 547 554.

Wibowo, S. 2007. Budidaya Bawang Putih, Bawang Merah, dan Bawang Bombay. Penebar Swadaya. Jakarta

Yuniastuti. 2006. Ekstraksi dan Identifikasi Komponen Sulfida pada Bawang Putih. Tugas akhir sarjana sains. Universitas Negeri Semarang. Semarang. 